Improved Y-STR typing for disaster victim identification, missing persons investigations, and historical human skeletal remains

\title{
Ambers, Angie
}

2018-11

Ambers , A , Votrubova , J , Vanek , D , Sajantila , A \& Budowle , B 2018 , ' Improved Y-STR typing for disaster victim identification, missing persons investigations, and historical human skeletal remains ' , International Journal of Legal Medicine , vol. 132 , no. 6 , pp. 1545-1553 . https://doi.org/10.1007

http://hdl.handle.net/10138/260561

https://doi.org/10.1007/s00414-018-1794-8

publishedVersion

Downloaded from Helda, University of Helsinki institutional repository.

This is an electronic reprint of the original article.

This reprint may differ from the original in pagination and typographic detail.

Please cite the original version. 


\title{
Improved Y-STR typing for disaster victim identification, missing persons investigations, and historical human skeletal remains
}

\author{
Angie Ambers ${ }^{1}$ (D) Jitka Votrubova ${ }^{2} \cdot$ Daniel Vanek $^{2,3,4} \cdot$ Antti Sajantila $^{5} \cdot$ Bruce Budowle $^{1,6}$
}

Received: 26 September 2017 / Accepted: 9 February 2018 /Published online: 23 February 2018

(C) Springer-Verlag GmbH Germany, part of Springer Nature 2018

\begin{abstract}
Bones are a valuable source ofDNA in forensic, anthropological, and archaeological investigations. There are a number of scenarios in which the only samples available for testing are highly degraded and/or skeletonized. Often it is necessary to perform more than one type of marker analysis on such samples in order to compile sufficient data for identification. Lineage markers, such as Y-STRs and mitochondrial DNA (mtDNA), represent important systems to complement autosomal DNA markers and anthropological metadata in making associations between unidentified remains and living relatives or for characterization of the remains for historical and archaeological studies. In this comparative study, Y-STR typing with both YfilerTM and Yfiler ${ }^{\mathrm{TM}}$ Plus (Thermo Fisher Scientific, Waltham, MA, USA) was performed on a variety of human skeletal remains, including samples from the American Civil War (1861-1865), the late nineteenth century gold rush era in Deadwood, SD, USA (1874-1877), the Seven Years' War (1756-1763), a seventeenth-century archaeological site in Raspenava, Bohemia (Czech Republic), and World War II (1939-1945). The skeletal remains used for this study were recovered from a wide range of environmental conditions and were extracted using several common methods. Regardless of the DNA extraction method used and the age/condition of the remains, 22 out of 24 bone samples yielded a greater number of alleles using the $Y$ filer ${ }^{\mathrm{TM}}$ Plus kit compared to the Yfiler $^{\mathrm{TM}}$ kit using the same quantity of input DNA. There was no discernable correlation with the degradation index values for these samples. Overall, the efficacy of the Yfiler ${ }^{\mathrm{TM}}$ Plus assay was demonstrated on degraded DNA from skeletal remains. Yfiler ${ }^{\mathrm{TM}}$ Plus increases the discriminatory power over the previous generation multiplex due to the larger set of Y-STR markers available for analysis and buffer modifications with the newer version kit. Increased haplotype resolution is provided to infer or refute putative genetic relationships.
\end{abstract}

Keywords Skeletal remains $\cdot$ Y-STR typing $\cdot$ Degraded DNA $\cdot$ Yfiler ${ }^{\text {TM }}$ Plus $\cdot$ Lineage testing $\cdot$ Historical remains Rapidly mutating Y-STRs

Electronic supplementary material The online version of this article (https://doi.org/10.1007/s00414-018-1794-8) contains supplementary material, which is available to authorized users.

Angie Ambers

angie.ambers2@unthsc.edu

1 Center for Human Identification, University of North Texas Health Science Center, Fort Worth, TX, USA

2 Forensic DNA Service, Prague, Czech Republic

3 2nd Faculty of Medicine, Charles University in Prague, Prague, Czech Republic

4 Institute of Legal Medicine, Bulovka Hospital, Prague, Czech Republic

5 Department of Forensic Medicine, University of Helsinki, Helsinki, Finland

6 Center of Excellence in Genomic Medicine Research (CEGMR), King Abdulaziz University, Jeddah, Saudi Arabia

\section{Introduction}

There are many scenarios encountered in forensic casework in which bone may be the only viable sample type for DNA testing, including fires, terrorist attacks, natural disasters, war conflicts, airline crashes, homicide, and mass graves from oppressive regimes [1-16]. In addition, skeletal remains often are the only samples available in historical and archaeological cases [17-22]. Skeletal remains are among the most challenging sample types for DNA testing due to prolonged exposure to a variety of environmental insults, including the effects of soil acidity. Humic and fulvic acids in soil damage DNA and, if copurified, inhibit PCR amplification. Since DNA recovered from bone often is degraded and in low quantities, autosomal STR typing sometimes fails or results in partial profiles which may not be sufficient for rendering an 
identification. In cases involving unidentified males, Ychromosome lineage markers can serve to supplement autosomal STR results and anthropological metadata to increase statistical confidence in identification efforts.

Although the accuracy of identification of skeletal remains increases as the number of relatives typed increases, in some cases the number of reference samples available can be quite limited [23, 24]. One approach to improving the power of identification is to type additional markers [23-29]. Lineage-based Y-chromosome markers can provide additional data to support or refute putative familial relationships. In some cases, lineage markers may be the only informative markers for making associations between unidentified remains and living relatives [23, 30-32].

Two early generation kits, PowerPlex ${ }^{\circledR}$ Y (Promega Corporation, Madison, WI, USA) and YfilerTM (Thermo Fisher Scientific, Waltham, MA, USA), contain reagents to simultaneously amplify 12 Y-STRs and 17 Y-STRs, respectively. Both of these kits contain the core Y-STR loci advocated by the Scientific Working Group on DNA Analysis Methods (SWGDAM) and the European minimal haplotype [33]. A considerable amount of effort has since been dedicated to identifying additional Y-STR loci that may increase the discriminatory power of Yhaplotype data, as well as be more effective for amplification of challenged samples [34-39]. Both PowerPlex ${ }^{\circledR}$ Y23 (Promega) and YfilerTM Plus (Thermo Fisher Scientific) are enhanced Y-STR multiplex kits that may increase the typing capability of Y-STRs in bone samples.

The YfilerTM Plus kit includes the 17 Y-STR markers from the original Y filer ${ }^{\mathrm{TM}}$ kit plus 10 additional highly polymorphic markers (DYS449, DYS460, DYS481, DYS518, DYS533, DYS570, DYS576, DYS627, and DYF387S1a/b). Seven of the ten additional loci included in the Yfiler ${ }^{\mathrm{TM}}$ Plus kit are rapidly mutating Y-STRs (DYS449, DYS518, DYS570, DYS576, DYS627, and DYF387S1a/b) [40]. Several validation and population genetic studies have been performed using the YfilerTM Plus kit [41-46], but none evaluating its ability to type DNA extracted from skeletal remains. Therefore, the study herein evaluated the efficacy of the Yfiler ${ }^{\mathrm{TM}}$ Plus kit for typing degraded DNA from human skeletal remains from the American Civil War (1861-1865) [17], the Black Hills Gold Rush in Deadwood, SD, USA (1874-1877) [18], the Seven Years' War (1756-1763) [47], a seventeenth-century archaeological site in Raspenava, Bohemia (Czech Republic), and World War II (1939-1945) [10]. Comparisons were made to the previous generation YfilerTM kit on equal amounts of DNA from the same skeletal remains samples. Various performance criteria for each kit were assessed, including total number of alleles detected, total signal (RFU) per locus, total average signal across all loci, inhibitor tolerance, and success with amplification of larger Y-STR loci, the latter of which often drop out of the profile in challenged samples.

\section{Materials and methods}

Protocols for minimizing contamination during handling and processing of the skeletal remains used in this study were the same contamination controls standardly recommended for archaeological and ancient DNA specimens, including (a) use of protective suits, gloves, and masks; (b) bleach decontamination and UV-irradiation of work benches and associated equipment; (c) physical removal and/or chemical destruction of contaminant/exogenous DNA on external bone surfaces; (d) extraction of bone samples in a designated lowcopy area; (e) PCR amplification in a location that is physically separated from the extraction area; (f) use of appropriate negative controls, reagent blanks, and positive controls; and (g) replicate testing [48-53].

\section{Human skeletal remains}

Historical bone samples included the 120-year-old skeletal remains (right femur, both tibiae) of an exhumed American Civil War soldier [17]; 140-year-old human skeletal remains from the Black Hills gold rush era, discovered by a construction crew in Deadwood, SD, USA [18]; a femur of a soldier from a mass grave in Liberec, Northern Bohemia, from the Battle of Reichenberg in 1757 between the Austrian and Prussian armies (a battle of the Seven Years' War) [47]; seventeenth century skeletal remains from an archaeological site in Raspenava, Bohemia (Czech Republic); and skeletal remains (femora) of three Finnish World War II soldiers [10].

\section{Bone processing and DNA extraction}

The diaphysis of each bone was surface-sanded with a Dremel ${ }^{\circledR} 4000$ Rotary Tool and sterile grinding stone (Robert Bosch Tool Corporation, Mount Prospect, IL, USA), followed by sectioning with a Stryker ${ }^{\circledR}$ autopsy saw (Mopec, Oak Park, MI, USA). DNA extractions with $0.5-1.0 \mathrm{~g}$ bone powder were performed in a designated low-copy number area of the laboratory using three different methods, as described in [17].

\section{DNA quantification}

The quantity of DNA in each extract was determined using the Quantifiler® Trio DNA Quantification Kit (Thermo Fisher Scientific) and an ABI 7500 Real-Time PCR System. The assay was carried out in a $20-\mu \mathrm{l}$ total reaction volume $(18 \mu \mathrm{l}$ Quantifiler ${ }^{\circledR}$ Trio master mix and $2 \mu$ DNA extract). Sample concentrations were determined by comparison to a standard curve. A degradation index (DI) was generated for each sample, and the quantification value for the small autosomal target was used to calculate total DNA input for downstream PCR applications (per manufacturer recommendations) [54]. 


\section{Amplification of Y-STR loci}

Amplifications with Y filer ${ }^{\mathrm{TM}}$ Plus and Yfiler ${ }^{\mathrm{TM}}$ kits were carried out according to the manufacturer's recommendations $[40,55]$. Thermal cycling was performed with an ABI GeneAmp ${ }^{\circledR} 9700$ PCR System (Thermo Fisher Scientific), and the same input quantity of DNA was used for both kits.

\section{DNA separation, detection, and analysis}

Amplified products were size-separated and detected on an ABI 3500xl Genetic Analyzer (Life Technologies) using $1 \mu \mathrm{l}$ PCR product, $9.6 \mu \mathrm{l} \mathrm{Hi-Di{ } ^ { \mathrm { TM } }}$ formamide, and $0.4 \mu \mathrm{l}$ GeneScan $^{\mathrm{TM}} 600$ LIZ $^{\mathrm{TM}}$ Size Standard v2.0 (Thermo Fisher Scientific). An allelic ladder was included at least once per injection on the 96-well plate. Samples were denatured at $95{ }^{\circ} \mathrm{C}$ for $5 \mathrm{~min}$ and then immediately cooled on ice for $5 \mathrm{~min}$. Electrophoresis was performed on a 36-cm capillary array with POP-4 ${ }^{\mathrm{TM}}$ polymer (Thermo Fisher Scientific) using standard injection parameters $(1.2 \mathrm{kV}, 24 \mathrm{~s})$. STR data were sized and typed with GeneMapper® ID-X Software Version 1.4 (Thermo Fisher Scientific) and analyzed using a common threshold of $75 \mathrm{RFU}$ for comparison of kit performance.

\section{Results and discussion}

DNA was not detected in any of the extraction reagent blanks or amplification negative controls. Positive controls (control DNA 007, human male) yielded the correct type in all Yfiler ${ }^{\mathrm{TM}}$ and $\mathrm{Yfiler}^{\mathrm{TM}}$ Plus reactions. A female analyst conducted all testing for each set of remains, including surface cleaning, bone grinding, DNA extractions, quantification, PCR amplifications, and genotyping. Male individuals involved in the exhumation or recovery of the remains and male laboratory personnel were excluded as contributors, supporting that the Y-STR haplotypes obtained were endogenous to the decedents. A common threshold of $75 \mathrm{RFU}$ was used in this study as a basis to compare performance between the kits. However, internal validation studies should be performed to formally establish analytical thresholds prior to implementation of the YfilerTM or Yfiler ${ }^{\mathrm{TM}}$ Plus assay into casework.

\section{Total number of alleles detected: Yfiler $^{\mathrm{Tm}}$ Plus versus Yfiler $^{\mathrm{TM}}$}

Figure 1 summarizes the total number of alleles detected for each bone sample after amplification with the Yfiler ${ }^{\mathrm{TM}}$ Plus and Yfiler ${ }^{\mathrm{TM}}$ kits. Although $1 \mathrm{ng}$ of input DNA is recommended for both Y-STR multiplexes, this target quantity was not available for the samples used in this study, a limitation commonly encountered with degraded skeletal remains. For this sample set, the range of input DNA was $0.100-0.827 \mathrm{ng}$. The total amount of input DNA, degradation index (DI), and total number of alleles detected for each bone sample is reported in Supplementary Table 1. Allele designations for the loci detected and in common between Yfiler ${ }^{\mathrm{TM}}$ and Yfiler ${ }^{\mathrm{TM}}$ Plus were concordant for all bone samples.
Fig. 1 Comparison of total number of Y-STR alleles recovered using the $\mathrm{Yfiler}^{\mathrm{TM}}$ and Yfiler ${ }^{\mathrm{TM}}$ Plus PCR amplification kits with the same quantity of input DNA (ng) from human skeletal remains from the American Civil War (18611865), the Black Hills Gold Rush era (1874-1877, Deadwood, SD, USA), the Seven Years' War (1756-1763), and a seventeenth century archaeological site in Raspenava, Czech Republic. Total input DNA and degradation indices (DIs) for each bone sample are reported in Supplementary Table 1
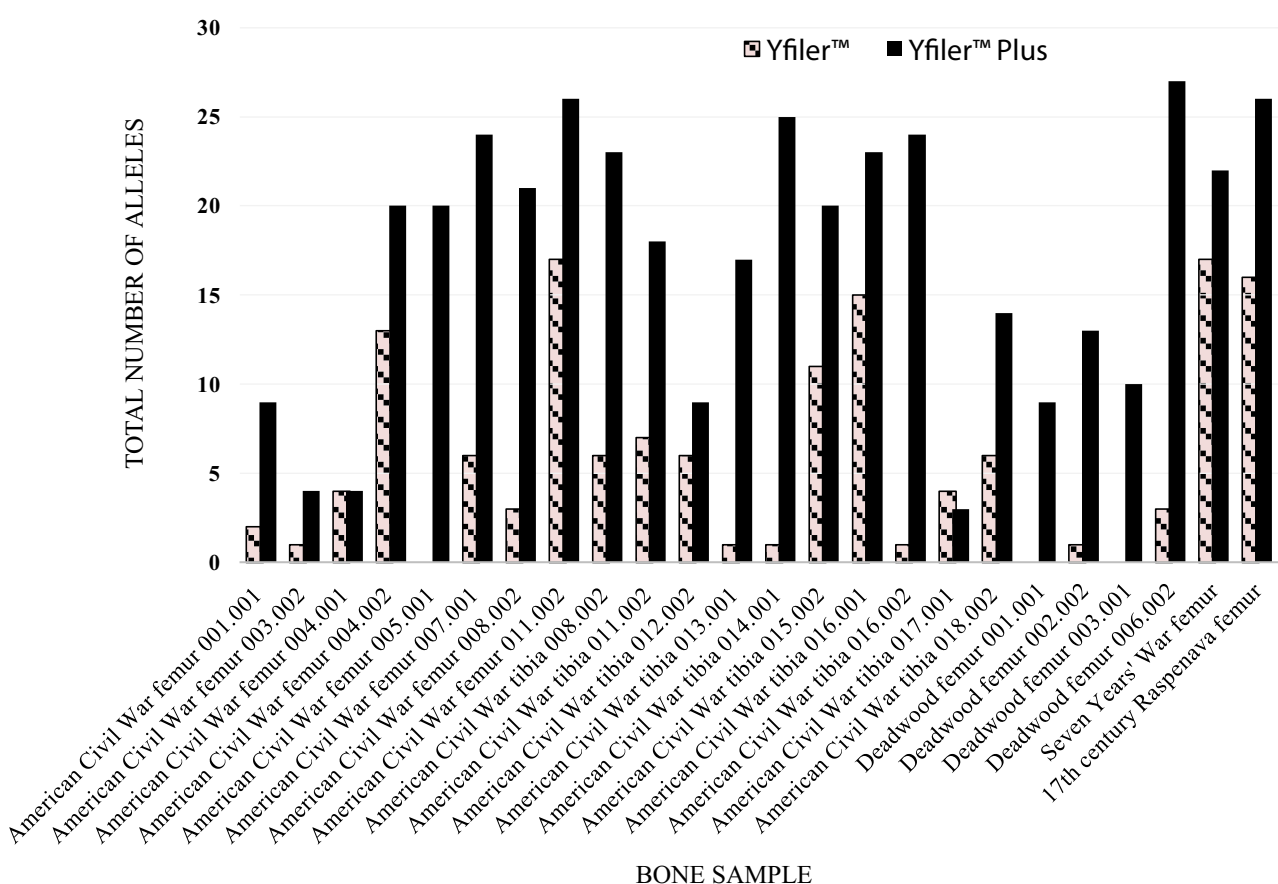

BONE SAMPLE 
Table 1 Number of bone samples with amplification success at the largest Y-STR loci in common between the Yfiler ${ }^{\mathrm{TM}}$ and Yfiler $^{\mathrm{TM}}$ Plus kits (total $n=24$ ). Amplicon sizes provided by Lisa Calandro and Julio Mulero, Thermo Fisher Scientific (personal communication)

\begin{tabular}{|c|c|c|c|c|}
\hline \multirow[b]{2}{*}{ Y-STR locus } & \multicolumn{2}{|c|}{ Amplicon size } & \multicolumn{2}{|c|}{$\begin{array}{l}\text { Number of bone samples with } \\
\text { amplification success }(n=24)\end{array}$} \\
\hline & Yfiler $^{\mathrm{TM}}$ & Yfiler $^{\mathrm{TM}}$ Plus & Yfiler $^{\mathrm{TM}}$ & Yfiler ${ }^{\mathrm{TM}}$ Plus \\
\hline DYS438 & $212-237 \mathrm{bp}$ & $212-237 \mathrm{bp}$ & 7 & 12 \\
\hline DYS635 & $246-270 \mathrm{bp}$ & $198-222$ bp & 11 & 18 \\
\hline DYS389II & 254-294 bp & 251-291 bp & 5 & 13 \\
\hline DYS385a/b & $243-315 b p$ & 229-301 bp & 6 & 15 \\
\hline DYS448 & $282-324 b p$ & $282-324 \mathrm{bp}$ & 10 & 20 \\
\hline DYS392 & 294-327 bp & $274-307 \mathrm{bp}$ & 4 & 11 \\
\hline
\end{tabular}

Out of 18 bone cuttings tested (eight femur, ten tibia) from an American Civil War soldier (with a range of 0.1000.440 ng input DNA), more alleles were detected for all samples using YfilerTM Plus except for one femur sample (004.001) and one tibia sample (017.001). For the femur sample, the same number of alleles was detected after amplification with both Yfiler ${ }^{\mathrm{TM}}$ and Yfiler ${ }^{\mathrm{TM}}$ Plus. The minimal data obtained (i.e., four alleles) likely is a consequence of DNA degradation, as indicated by the degradation index (DI 8.39) for this sample, which was the highest among the cuttings from this set of remains. The latter sample (tibia 017.001) had a much lower DI (3.32), but minimal data also were observed, and slightly more alleles were detected using Yfiler ${ }^{\mathrm{TM}}$ compared to Yfiler ${ }^{\mathrm{TM}}$ Plus (i.e., four alleles and three alleles, respectively). Although the input quantities varied slightly among samples analyzed, there was not a strong correlation observed between DI values and typing success for these samples and the other remains tested in this study.

Four femur cuttings from the skeleton of a pioneer from the Black Hills Gold Rush era (1874-1877) were tested, all of which yielded a higher number of alleles with Y filer ${ }^{\mathrm{TM}}$ Plus. The sample with the lowest DI (6.99) and greatest amount of input DNA (0.626 ng) yielded the most alleles. Moreover, there was a notable difference in typing success with this sample (as well as the others from this set of remains), resulting in a complete 27-locus Yfiler ${ }^{\text {TM }}$ Plus Y-STR haplotype compared to recovery of only three alleles using the $\mathrm{Yfiler}^{\mathrm{TM}}$ kit.

The femur of a soldier from a battle of the Seven Years' War (1756-1763) yielded 17 and 22 Y-STR alleles with Y filer ${ }^{\mathrm{TM}}$ and Yfiler ${ }^{\mathrm{TM}}$ Plus, respectively, even with less than half the recommended input DNA of $1 \mathrm{ng}$. For another set of remains from the Czech Republic, recovered from a seventeenth-century archaeological site in Raspenava, Bohemia, Yfiler ${ }^{\mathrm{TM}}$ Plus and Yfiler ${ }^{\mathrm{TM}}$ both performed well (16 alleles and 26 alleles, respectively). Detailed locus-by-locus data for each kit for each bone sample from the American Civil War, late nineteenth-century Deadwood, the Seven Years' War, and the seventeenth century archaeological site in Raspenava, Bohemia are reported in Supplementary Table 2.
Since the amount of sample from the skeletal remains of three Finnish World War II soldiers was limited, these bone samples were typed only with Y filer $^{\mathrm{TM}}$ Plus due to the increased recovery of Y-STR genetic data observed with this kit. With a DI as high as 13.15 and with less than $1 \mathrm{ng}$ input DNA for each sample $(0.381$, 0.664, and $827 \mathrm{ng}$ ), all three World War II bone samples yielded a greater number of alleles than would have been possible with the previous generation Yfiler ${ }^{\mathrm{TM}}$ kit $(19,21$, and 27 alleles, respectively, compared to a maximum of 17 Y-STRs with Yfiler ${ }^{\mathrm{TM}}$ ) (Supplementary Table 1). One sample (femur 2011-287-1163) yielded a complete 17-locus haplotype for the common loci amplified by both Yfiler ${ }^{\mathrm{TM}}$ and Yfiler ${ }^{\mathrm{TM}}$ Plus, as well as a full 27-locus Yfiler $^{\mathrm{TM}}$ Plus profile. For the other two World War II bone samples (femur 2010-224-1548 and femur 2011-104-310), only 14- and 13-allele haplotypes were obtained (respectively) for the 17 common loci between the kits. Although these samples were not tested with the earlier generation Yfiler ${ }^{\mathrm{TM}}$ assay, the results using YfilerTM Plus exceed the maximum possible haplotype with Yfiler $^{\mathrm{TM}}$. The additional data recovered for these samples using Yfiler ${ }^{\mathrm{TM}}$ Plus (ten alleles, five alleles, and seven alleles, respectively) increases the discriminatory power for identification of these soldiers' remains. Detailed locus-by-locus Y filer ${ }^{\mathrm{TM}}$ Plus data for each World War II bone sample are reported in Supplementary Table 3 .

\section{Performance with larger Y-STR loci}

Although a multiplex with a greater number of loci increases discriminatory power, another important consideration for degraded samples is amplicon size and potential inhibition. Skeletal remains often contain DNA of limited quantity and compromised quality, both of which contribute to reduction or loss of signal at larger loci. In these types of samples, incomplete genetic profiles due to allele and/or locus drop-out are well documented [17, 18, 56-60]. Therefore, due to the degraded nature and/or quality of the bone samples used in this study, the performance of the seven largest loci that are common between the two kits (DYS385a/b, DYS389II, DYS392, DYS438, DYS448, DYS635) was compared (Table 1). Out of 
Table 2 Comparison of the performance of Yfiler ${ }^{\mathrm{TM}}$ Plus versus Yfiler $^{\mathrm{TM}}$ on the same set of bone samples using the same quantity of input DNA: (A) total number of alleles detected using the Yfiler ${ }^{\mathrm{TM}}$ kit only; (B) total number of alleles observed using Yfiler ${ }^{\mathrm{TM}}$ Plus that were common and concordant with Y filer $^{\mathrm{TM}}$ amplification results; (C) number of additional alleles observed for the 17 loci in common between the two kits (i.e., alleles observed using Yfiler ${ }^{\mathrm{TM}}$ Plus but not observed in Yfiler ${ }^{\mathrm{TM}}$ only results); and (D) number of additional alleles observed for loci included only in the Yfiler ${ }^{\mathrm{TM}}$ Plus kit $(n=10$ loci)

\begin{tabular}{|c|c|c|c|c|}
\hline Bone sample & $\begin{array}{l}\text { A } \\
\text { Total number of } \\
\text { alleles observed } \\
\text { (Yfiler }{ }^{\mathrm{TM}} \text { only) }\end{array}$ & $\begin{array}{l}\text { B } \\
\text { Number of common } \\
\text { alleles observed } \\
\text { (Yfiler }{ }^{\mathrm{TM}} \text { Plus) }\end{array}$ & $\begin{array}{l}\mathrm{C} \\
\text { Number of additional } \\
\text { Yfiler }^{\mathrm{TM}} \text { alleles observed } \\
\text { using Y } \text { filer }^{\mathrm{TM}} \text { Plus }\end{array}$ & $\begin{array}{l}\text { D } \\
\text { Number of additional } \\
\text { alleles observed } \\
\text { (Yfiler }{ }^{\mathrm{TM}} \text { Plus loci only, } n=10 \text { ) }\end{array}$ \\
\hline American Civil War femur 001.001 & 2 & 2 & 3 & 4 \\
\hline American Civil War femur 003.002 & 1 & 0 & 2 & 2 \\
\hline American Civil War femur 004.001 & 4 & 0 & 1 & 3 \\
\hline American Civil War femur 004.002 & 13 & 12 & 2 & 6 \\
\hline American Civil War femur 005.001 & 0 & 0 & 14 & 6 \\
\hline American Civil War femur 007.001 & 6 & 5 & 11 & 8 \\
\hline American Civil War femur 008.002 & 3 & 2 & 12 & 7 \\
\hline American Civil War femur 011.002 & 17 & 17 & 0 & 9 \\
\hline American Civil War tibia 008.002 & 6 & 6 & 10 & 7 \\
\hline American Civil War tibia 011.002 & 7 & 6 & 7 & 5 \\
\hline American Civil War tibia 012.002 & 6 & 3 & 3 & 3 \\
\hline Aemrican Civil War tibia 013.001 & 1 & 1 & 10 & 6 \\
\hline American Civil War tibia 014.001 & 1 & 1 & 16 & 8 \\
\hline American Civil War tibia 015.002 & 11 & 9 & 5 & 6 \\
\hline American Civil War tibia 016.001 & 15 & 15 & 2 & 6 \\
\hline American Civil War tibia 016.002 & 1 & 1 & 16 & 7 \\
\hline American Civil War tibia 017.001 & 4 & 0 & 1 & 2 \\
\hline American Civil War tibia 018.002 & 6 & 5 & 4 & 5 \\
\hline Deadwood femur 001.001 & 0 & 0 & 7 & 2 \\
\hline Deadwood femur 002.002 & 1 & 1 & 8 & 4 \\
\hline Deadwood femur 003.001 & 0 & 0 & 6 & 4 \\
\hline Deadwood femur 006.002 & 3 & 3 & 14 & 10 \\
\hline Seven Years' War femur & 17 & 16 & 0 & 6 \\
\hline Seventeenth century Raspenava femur & 16 & 16 & 0 & 10 \\
\hline
\end{tabular}

24 bone samples tested, higher success rates for the larger common loci were achieved with the Yfiler ${ }^{\mathrm{TM}}$ Plus kit compared to the Yfiler ${ }^{\mathrm{TM}}$ kit. These data suggest that the Yfiler $^{\mathrm{TM}}$ Plus kit can overcome inhibition of the downstream assay better than the Yfiler ${ }^{\mathrm{TM}}$ kit.

Results for the remaining ten loci that are common between the two kits are reported in Supplementary Table 4. Because these loci are smaller, detection and typing success generally is greater in degraded samples. For these ten common loci, typable results were obtained for more bone samples using Yfiler ${ }^{\mathrm{TM}}$ Plus compared to Yfiler ${ }^{\mathrm{TM}}$ for every locus except DYS391 and DYS437. For the DYS391 locus, 14 bone samples yielded typable results with the Yfiler ${ }^{\mathrm{TM}}$ kit compared to only ten bone samples using the Yfiler ${ }^{\mathrm{TM}}$ Plus kit. This finding likely is due to a different primer set used during amplification with the YfilerTM Plus multiplex, which results in a larger amplicon size for that marker (i.e., 353-377 bp compared to $152-176 \mathrm{bp}$ in Yfiler $\left.{ }^{\mathrm{TM}}\right)$. The opposite pattern was observed with the Y-GATA-H4 locus, in which the amplicon size in the Yfiler $^{\mathrm{TM}}$ kit was much smaller than in the Yfiler ${ }^{\mathrm{TM}}$ Plus kit (122-142 bp compared to 227-247 bp, respectively), yet more bone samples yielded typable results with the Yfiler ${ }^{\mathrm{TM}}$ Plus kit. In the case of DYS437, results were obtained for an equal number of samples (19 out of 24 bones tested) with each kit.

Because the same DNA extracts and an equal amount of input DNA were used for amplification with each kit, the overall improved performance observed with Y filer ${ }^{\mathrm{TM}}$ Plus compared to Yfiler ${ }^{\mathrm{TM}}$ on the same bone samples suggests that Yfiler ${ }^{\mathrm{TM}}$ Plus is more robust than its previous generation counterpart.

\section{Sensitivity assessment: Yfiler ${ }^{\mathrm{Tm}}$ Plus versus Yfiler $^{\mathrm{Tm}}$}

In addition to increased discriminatory power and successful typing of larger Y-STR loci, an equal or improved level of sensitivity of detection is desirable for forensic casework. The low-signal (RFU) data encountered in analyses of bone 
samples is an important consideration in assay selection. If addition of more loci to a multiplex reduces overall signal and performance, it may not be desirable for use with challenging casework samples. Even minimal reduction in signal across loci presents a risk of potentially losing valuable genetic data that could have otherwise been detected using a smaller, less discriminatory assay.

For the majority of bone samples tested (20 out of 24), Yfiler $^{\mathrm{TM}}$ Plus performed the same or comparably (within one allele) on the common alleles observed from the Yfiler $^{\mathrm{TM}}$ amplifications (Table 2, columns A-B). Allele designations were concordant between the two kits for all samples (Supplementary Table 2A). More importantly, for most of the samples (21 out of 24) undetected Yfiler $^{\mathrm{TM}}$ alleles were recovered with Yfiler ${ }^{\mathrm{TM}}$ Plus amplifications (column C) as well as the ancillary benefit of detection of additional alleles with the expanded loci (column D). These observations further support that the Yfiler ${ }^{\mathrm{TM}}$ Plus kit is a more robust assay both in terms of sensitivity and in overcoming inhibition.

A general pattern observed was that samples which performed well with Yfiler ${ }^{\mathrm{TM}}$ also performed well with Yfiler $^{\mathrm{TM}}$ Plus. However, some samples yielding poor results with YfilerTM $^{\mathrm{TM}}$ were substantially improved with Yfiler ${ }^{\mathrm{TM}}$ Plus. For example, although two of the Deadwood bone samples (femur 001.001, femur 003.001) yielded no typable data with Yfiler ${ }^{\mathrm{TM}}$, partial profiles of nine alleles and ten alleles, respectively, were obtained using Yfiler ${ }^{\mathrm{TM}}$ Plus. In another case, a complete 27locus Y-STR haplotype was obtained using Yfiler ${ }^{\mathrm{TM}}$ Plus for a sample which yielded only three detectable alleles using Yfiler $^{\text {TM }}$ (Deadwood femur 006.002, Table 2, Supplementary Table 2). Furthermore, although complete 17-locus Yfiler ${ }^{\mathrm{TM}}$ profiles were obtained for two bones in this sample set (American Civil War femur 011.002, Seven Years' War femur), additional data was obtained when the samples were amplified using Yfiler ${ }^{\mathrm{TM}}$ Plus (nine additional alleles and five additional alleles, respectively), improving the discriminatory power.

In terms of signal intensity, there was a reduction in total average signal (RFU) per locus for some samples using Yfiler $^{\mathrm{TM}}$ Plus, while signal was comparable between the two assays for other samples. For the Seven Years' War femur and the seventeenth century Raspenava archaeological femur, signal intensity decreased for almost every locus using Yfiler ${ }^{\mathrm{TM}}$ Plus compared to Yfiler ${ }^{\mathrm{TM}}$ (Supplementary Table 2B). However, the Yfiler ${ }^{\mathrm{TM}}$ Plus reactions generated additional genetic data for identification (six alleles and ten alleles, respectively; Supplementary Table 2A). For one of the American Civil War samples (femur 011.002), signal for all loci common between the two kits was comparable and alleles for five loci exclusive to the Yfiler ${ }^{\mathrm{TM}}$ Plus assay were detected (Supplementary Table 2). In another American Civil war bone sample (tibia 016.001), signal at 12 of the 17 common loci was increased using Yfiler ${ }^{\mathrm{TM}}$ Plus and was supplemented with detection of alleles at six of the ten additional loci included in the Yfiler ${ }^{\mathrm{TM}}$ Plus assay.
For the ten additional loci included in the Yfiler ${ }^{\mathrm{TM}}$ Plus multiplex, an average of six additional alleles was obtained across all bone samples (range 2-10 alleles, Table 2, column D). This data provides improved discriminatory power than could have been possible using the earlier generation $\mathrm{Yfiler}^{\mathrm{TM}}$ assay. The potential for increased data acquisition from the same quantity of DNA using Yfiler ${ }^{\mathrm{TM}}$ Plus warrants its consideration for use with challenged forensic samples types such as skeletal remains and bone fragments.

\section{Value of rapidly mutating Y-STRs}

Another important potential benefit of the YfilerTM Plus kit relates to the assay's inclusion of rapidly mutating Y-STRs. Some studies have shown that rapidly mutating Y-STRs can increase the power of discrimination between unrelated males as well as between males of the same patrilineage [61-64]. In a study of 305 males from 127 separate familial pedigrees, the rapidly mutating Y-STR panel included in Y filer ${ }^{\mathrm{TM}}$ Plus could distinguish between (1) $48.7 \%$ of fathers and sons, (2) $60 \%$ of brothers, and (3) $75 \%$ of male cousins. The discriminatory power of the previous generation ffiler $^{\mathrm{TM}}$ kit was considerably less with the same data set, at $7.7 \%, 8 \%$, and $25 \%$, respectively [62]. This increased ability to distinguish between related males could have considerable application for mass disaster scenarios in which multiple victims from the same family were traveling together, as well as for mass graves from past war conflicts (which may contain related male soldiers) and for mass graves containing multi-generational victims of oppressive regimes.

Although the rapidly mutating loci included in the Yfiler ${ }^{\mathrm{TM}}$ Plus kit could help improve the ability to discriminate between closely related male victims within a mass grave or male relatives killed in the same mass disaster, there is a potential additional complication that should be considered. The rapid mutation rate that provides increased discriminatory power between males of the same patrilineage also increases the possibility of detecting differences between male victims and reference samples of living relatives. This will make kinship testing with rapidly mutating Y-STRs more challenging. Mutations could result in false exclusions or the resultant likelihood ratio may be so diminished that the Y-STR data may not be informative. This must be taken into account when making an association or identification.

\section{Conclusion}

Y-STRs provide a valuable addition to other tools used (e.g., autosomal STRs, anthropological analyses) in identifying male skeletal remains. The Yfiler ${ }^{\text {TM }}$ Plus multiplex of 27 Y-STRs offers greater power of discrimination than the previous generation 17-locus Yfiler ${ }^{\mathrm{TM}}$ kit as well as an overall increased robustness. A previous study with two models of inhibition, humic acid and 
hematin, demonstrated that the Yfiler Plus ${ }^{\mathrm{TM}}$ kit was more robust to inhibition than the Yfiler ${ }^{\mathrm{TM}}$ kit [41]. Furthermore, the design of the YfilerTM Plus assay, with inclusion of eleven mini Y-STR loci ( $<220 \mathrm{bp}$ ), facilitates successful amplification of degraded templates $[40,41]$. This study demonstrates that the improved polymerase and buffer systems in Yfiler ${ }^{\mathrm{TM}}$ Plus result in better performance on degraded DNA from human skeletal remains than the earlier generation assay. The skeletal remains used in this study were recovered from a variety of geographic locations, including both eastern and western regions of the United States, Russia, and the Czech Republic. The diverse environments to which the remains were exposed likely resulted in varying degrees of DNA damage as well as different combinations of lesions, each of which posed a unique challenge for $Y_{\text {filer }}^{\mathrm{TM}}$ and YfilerTM Plus chemistry. The results demonstrate the efficacy of YfilerTM Plus on a diverse sample set of bones, which can be some of the most difficult samples for forensic analyses.

Acknowledgements This project was supported in part by Thermo Fisher Scientific, the City of Deadwood, Deadwood Historical Preservation Society, Department of Forensic Medicine at the University of Helsinki, and the Czech Science Foundation (grant No. 14-36938G). We would like to thank Thermo Fisher Scientific for donation of reagents for amplification and genotyping; and Andrea Carbonaro, Laura Pelleymounter, Lisa Calandro, and Julio Mulero for their technical assistance, expertise, and accurate amplicon sizing data for the Y-STR kits used in this study. The opinions, findings, and conclusions or recommendations expressed in this publication are those of the author(s) and do not necessarily reflect those of Thermo Fisher Scientific, the City of Deadwood, Deadwood Historical Preservation Society, University of Helsinki, or the Czech Science Foundation.

\section{References}

1. Turney L (2010) The failure of DNA forensic testing: a case study of the 2009 Australian bushfire disaster. J New Genet Soc 29:225240

2. Hartman D, Drummer O, Eckhoff C, Scheffer JW, Stringer P (2011) The contribution of DNA to the disaster identification effort. Forensic Sci Int 205:52-58

3. Riccia U, Carbonia I, Iozzia S, Nutinia AL, Continia E, Torricellia F, Focardib M, Pinchib V, Marib F, Norelli GA (2015) Genetic identification of burned corpses as a part of disaster victim identification effort. Forensic Sci Int Genet Supp Ser 5:e447-e448

4. Biesecker LG, Bailey-Wilson JE, Ballantyne J, Baum H, Bieber FR, Brenner C, Budowle B, Butler JM, Carmody G, Conneally PM, Duceman B, Eisenberg A, Forman L, Kidd KK, Leclair B, Niezgoda S, Parsons TJ, Pugh E, Shaler R, Sherry ST, Sozer A, Walsh A (2005) DNA identifications after the 9/11 world trade center attack. Science 310:1122-1123

5. Brenner $\mathrm{CH}$, Weir BS (2003) Issues and strategies in the DNA identification of world trade center victims. Theor Popul Biol 63: 173-178

6. Holland MM, Cave CA, Holland CA, Bille TW (2003) Development of a quality, high throughput DNA analysis procedure for skeletal samples to assist with the identification of victims from the world trade center attacks. Croat Med J 44:264-272

7. Deng YJ, Li YZ, Yu XG, Li L, Wu DY, Zhou J, Man TY, Yang G, Yan JW, Cai DQ, Wang J, Yang HM, Li SB, Yu J (2005)
Preliminary DNA identification for the tsunami victims in Thailand. Genomics Proteomics Bioinformatics 3:143-157

8. Donkervoort S, Dolan SM, Beckwith M, Northrup TP, Sozer A (2008) Enhancing accurate data collection in mass fatality kinship identifications: lessons learned from hurricane Katrina. Forensic Sci Int Genet 2:354-362

9. Holland MM, Fisher DL, Mitchell LG, Rodriquez WC, Canik JJ, Merril CR, Weedn VW (1993) Mitochondrial DNA sequence analysis of human skeletal remains: identification of remains from the Vietnam War. J Forensic Sci 38:542-553

10. Palo J, Hedman M, Soderholm N, Sajantila A (2007) Repatriation and identification of Finnish World War II soldiers. Croat Med J 48: 528-535

11. Lee HY, Kim NY, Park MJ, Sim JE, Yang WI, Shin KJ (2010) DNA typing for the identification of old skeletal remains from Korean War victims. J Forensic Sci 55:1422-1429. https://doi.org/10.1111/ j.1556-4029.2010.01411.x

12. Pajnic IZ, Pogorelc BG, Balazic J (2010) Molecular genetic identification of skeletal remains from the second World War Konfin I mass grave in Slovenia. Int J Legal Med 124:307-317

13. Leclair B, Fregeau CJ, Bowen KL, Fourney RM (2004) Enhanced kinship analysis and STR-based DNA typing for human identification in mass fatality incidents: the Swissair flight 111 disaster. J Forensic Sci 49:939-953

14. Ludes B, Tracqui A, Pfitzinger H, Kintz P, Levy F, Disteldorf M, Hutt JM, Kaess B, Haag R, Memheld B et al (1994) Medico-legal investigations of the Airbus, A230 crash upon Mount Ste-Odile, France. J Forensic Sci 39:1147-1152

15. Olaisen B, Stenersen M, Mevag B (1997) Identification by DNA analysis of the victims of the August 1996 Spitsbergen civil aircraft disaster. Nat Genet 15:402-405

16. Huffine E, Crews J, Kennedy B, Bomberger K, Zinbo A (2001) Mass identification of persons missing from the break-up of the former Yugoslavia: structure, function, and role of the international commission on missing persons. Croat Med J 42:271-275

17. Ambers A, Gill-King H, Dirkmaat D, Benjamin R, King J, Budowle B (2014) Autosomal and Y-STR analysis of degraded DNA from the 120-year-old skeletal remains of Ezekiel harper. Forensicic Sci Int Genet 9:33-41

18. Ambers AD, Churchill JD, King JL, Stoljarova M, Gill-King H, Assidi M, Abu-Emalgd M, Buhmeida A, Al-Qahtani M, Budowle B (2016) More comprehensive forensic genetic marker analyses for accurate human remains identification using massively parallel DNA sequencing. BMC Genomics 17:750. https://doi.org/10. 1186/s12864-016-3087-2

19. Vanek D, Saskova L, Koch H (2002) Kinship and Y-chromosome analysis of $7^{\text {th }}$ century human remains: novel DNA extraction and typing procedure for ancient material. Croatian. Med J 50:286-295

20. Coble MD, Loreille OM, Wadhams MJ, Edson SM, Maynard K, Meyer CE, Niederstatter H, Berger C, Berger B, Falsetti AB, Gill P, Parson W, Finelli LN (2009) Mystery solved: the identification of the two missing Romanov children using DNA analysis. PLoS One 4:e4838. https://doi.org/10.1371/journal.pone.0004838

21. Gill P, Ivanov PL, Kimpton C, Piercy R, Benson N, Tully G, Evett I, Hagelberg E, Sullivan K (1994) Identification of the remains of the Romanov family by DNA analysis. Nat Genet 6:130-136

22. Ivanov PL, Wadhams MJ, Roby RK, Holland MM, Weedn VW, Parsons TJ (1996) Mitochondrial DNA sequence heteroplasmy in the Grand Duke of Russia Georgij Romanov establishes the authenticity of the remains of the Tsar Nicholas II. Nat Genet 12:417-420

23. Ge J, Budowle B, Chakraborty R (2011) Choosing relatives for DNA identification of missing persons. J Forensic Sci 56:S23-S28

24. Prinz M, Carracedo A, Mayr WR, Morling N, Parsons TJ, Sajantila A, Scheithauer R, Scmitter H, Schneider PM(2007) DNA Commission of the International Society for forensic genetics (ISFG): 
recommendations regarding the role of forensic genetics for disaster victim identification (DVI). Forensicic Sci Int Genet 1:3-12

25. Zietkiewicz E, Witt M, Daca P, Zebracka-Gala J, Goniewicz M, Jarzab B, Witt M (2012) Current genetic methodologies in the identification of disaster victims and in forensic analysis. J Appl Genet 53:41-60

26. Kayser M, de Kniff P (2011) Improving human forensics through advances in genetics, genomics, and molecular biology. Nat Rev Genet 12:179-192

27. Jobling MA, Gill P (2004) Encoding evidence: DNA in forensic analysis. Nat Rev Genet 5:739-752

28. Decorte R (2010) Genetic identification in the $21^{\text {st }}$ century - current status and future developments. Forensicic Sci Int Genet 201:160-164

29. Irwin JA, Edson SM, Loreille O, Just RS, Barritt SM, Lee DA, Holland TD, Parsons TJ, Leney MD (2007) DNA identification of "earthquake McGoon" 50 years postmortem. J Forensic Sci 52:1115-1118

30. Roewer L (2009) Y chromosome STR typing in crime casework. Forensicic Sci Med Pathol 5:77-84

31. Gill P, Brenner C, Brinkman B, Budowle B, Carracedo A, Jobling MA, de Kniff P, Kayser M, Krawczak M, Mayr W, Morling N, Olaisen B, Pascali V, Prinz M, Roewer L, Schneider PM, Sajantila A, Tyler-Smith C (2001) DNA Commission of the International Society of Forensic Genetics: recommendations on forensic analysis using Y-chromosome STRs. Forensic Sci Int 124:5-10

32. Corach D, Risso LF, Marino M, Penacino G, Sala A (2001) Routine Y-STR typing in forensic casework. Forensic Sci Int 118:131-135

33. Scientific Working Group on DNA Analysis Methods (SWGDAM), Interpretation guidelines for Y-chromosome STR typing, https://www.swgdam.org/publications

34. Lim SK, Xue Y, Parkin EJ, Tyler-Smith C (2007) Variation of 52 new Y-STR loci in the Y chromosome consortium worldwide panel of 76 diverse individuals. Int J Legal Med 121:124-127

35. Vermeulen M, Wollstein A, van der Gaag K, Lao O, Xue Y, Wang Q, Roewer L, Knoblauch H, Tyler-Smith C, de Kniff P, Kayser M (2009) Improving global and regional resolution of male lineage differentiation by simple single-copy Y-chromosomal short tandem repeat polymorphisms. Forensicic Sci Int Genet 3:205-213

36. Geppert M, Edelmann J, Lessig R (2009) The Y-chromosomal STRs DYS481, DYS570, DYS576 and DYS643. Legal Med 11: S109-S110

37. Rodig H, Roewer L, Gross A, Richter T, de Kniff P, Kayser M, Brabetz W (2008) Evaluation of haplotype discrimination capacity of 35 Y-chromosomal short tandem repeat loci. Forensic Sci Int 174:182-188

38. Kayser M, Kittler R, Erler A, Hedman M, Lee AC, Mohyuddin A, Qasim Mehdi S, Rosser Z, Stoneking M, Jobling MA, Sajantila A, Tyler-Smith C (2004) A comprehensive survey of human Ychromosomal microsatellites. Am J Hum Genet 74:1183-1197

39. D'Amato ME, Ehrenreich L, Cloete K, Benjeddou M, Davison S (2010) Characterization of the highly discriminatory loci DYS449, DYS481, DYS518, DYS612, DYS626, DYS644 and DYS710. Forensic Sci Int Genet 4:104-110

40. Yfiler ${ }^{\mathrm{TM}}$ Plus PCR amplification kit user guide, Publication number 4485610 Revision C, https://tools.thermofisher.com/content/sfs/ manuals/4485610_YfilerPlus_UG.pdf

41. Gopinath S, Zhong C, Nguyen V, Ge J, Lagace RE, Short ML, Mulero JJ (2016) Developmental validation of the Yfiler ${ }^{\circledR}$ Plus PCR amplification kit: an enhanced Y-STR multiplex for casework and database applications. Forensic Sci Int Genet 24:164-175

42. Rapone C, D'Atanasio E, Agostino A, Mariano M, Papaluca MT, Cruciani F, Berti A (2016) Forensic genetic value of a 27 Y-STR loci multiplex (Yfiler® Plus kit) in an Italian population sample. Forensic Sci Int Genet 21:e1-e5
43. Pickrahn I, Muller E, Zahrer W, Dunkelmann B, Cemper-Kielsslich J, Kreindl G, Neuhuber F (2016) Yfiler® Plus amplification kit validation and calculation of forensic parameters for two Austrian populations. Forensic Sci Int Genet 21:90-94

44. Ottaviani E, Vernarecci S, Asili P, Agostino A, Montagna P (2015) Preliminary assessment of the prototype Yfiler ${ }^{\circledR}$ Plus kit in a population study of northern Italian males. Int J Legal Med 129:729-730

45. Olofsson JK, Mogensen HS, Buchard A, Borsting C, Morling N (2015) Forensic and population genetic analyses of Danes, Greenlanders and Somalis typed with the Yfiler® Plus PCR amplification kit. Forensic Sci Int Genet 16:232-236

46. Ballantyne J, Hanson E, Green R, Holt A, Mulero J (2013) Enhancing the sexual assault workflow: testing of next generation DNA assessment and Y-STR systems. Forensic Sci Int Genet Suppl Ser 4:e228-e229

47. Votrubova-Dubska J, Vanek D, Zimund J, Mestek O, Urbanova V, Brzobohata H, Brestovansky P (2016) Technical note: efficient removal of a PCR inhibitory agent (vivianite) found on excavated bones. Forensic Sci Int Genet 261:8-13

48. Cooper A, Poinar HN (2000) Ancient DNA: do it right or not at all. Science 18:1139-1141

49. Yang DY, Watt K (2005) Contamination controls when preparing archaeological remains for ancient DNA analysis. J Archaeol Sci 32:331-336

50. Kemp BM, Smith DG (2005) Use of bleach to eliminate contaminating DNA from the surface of bones and teeth. Forensic Sci Int 154:53-61

51. Poinar HN (2003) Criteria of authenticity for DNA from ancient and forensic samples. Int Congr Ser 1239:575-579

52. Gilbert MTP, Hansen AJ, Willerslev E, Turner-Walker G, Collins M (2006) Insights into the processes behind the contamination of degraded human teeth and bone samples with exogenous sources of DNA. Int J Osteoarchaeol 16:156-164

53. Taberlet P, Griffin S, Goossens B, Questiau S, Manceau V, Escaravage N, Waits LP, Bouvet J (1996) Reliable genotyping of samples with very low DNA quantities using PCR. Nucleic Acids Res 24:3189-3194

54. Quantifiler® HP and Trio DNA Quantification Kits User Guide, Applied Biosystems Publication Number 4485354 Revision E, https://tools.thermofisher.com/content/sfs/manuals/4485354.pdf

55. AmpFlSTR ${ }^{\circledR}$ Y filer $^{\mathrm{TM}}$ PCR amplification kit user's manual, Part number 4358101 Revision C, https://www.thermofisher.com/ content/dam/LifeTech/Documents/PDFs/Y-STR/yfiler-usersmanual.pdf

56. Bar W, Kratzer A, Machler M, Schmid W (1988) Postmortem stability of DNA. Forensic Sci Int 39:59-70

57. Alvarez Garcia A, Munoz I, Pestoni C, Lareu MV, RodriguezCalvo MS, Carracedo A (1996) Effect of environmental factors on PCR DNA analysis from dental pulp. Int J Legal Med 109: $125-129$

58. Pfeiffer H, Huhne J, Seitz B, Brinkmann B (1999) Influence of soil storage and exposure period on DNA recovery from teeth. Int $\mathrm{J}$ Legal Med 112:142-144

59. Whitaker JP, Clayton TM, Urquhart AJ, Millican ES, Downes TJ, Kimpton CP, Gill P (1995) Short tandem repeat typing of bodies from a mass disaster: high success rate and characteristic amplification patterns in highly degraded samples. BioTechniques 18:670-677

60. Schneider PM, Bender K, Mayr WR, Parson W, Hoste B, Decorte R, Cordonnier J, Vanek D, Morling N, Karjalainen M, Marie-Paule Carlotti C, Sabatier M, Hohoff C, Schmitter H, Pflug W, Wenzel R, Patzelt D, Lessig R, Dobrowolski P, O'Donnell G, Garafano L, Dobosz M, de Knijff P, Mevag B, Pawlowski R, Gusmão L, Conceicao Vide M, Alonso Alonso A, García Fernández O, Sanz Nicolás P, Kihlgreen A, Bär W, Meier V, Teyssier A, Coquoz R, Brandt C, Germann U, Gill P, Hallett J, Greenhalgh M (2004) STR 
analysis of artificially degraded DNA - results of a collaborative European exercise. Forensic Sci Int 139:123-134

61. Ballantyne KN, Goedbloed M, Fang R, Schaap O, Lao O, Wollstein A, Choi Y, van Duijn K, Vermeulen M, Brauer S, Decorte R, Poetsch M, von Wurmb-Schwark N, de Knijff P, Labuda D, Vezina H, Knoblauch H, Lessig R, Roewer L, Ploski R, Dobosz T, Henke L, Henke J, Furtado MR, Kayser M (2010) Mutability of Y-chromosomal microsatellites: rates, characteristics, molecular bases, and forensic implications. Am J Hum Genet 87:341-353

62. Ballantyne KN, Keerl V, Wollstein A, Choi Y, Zuniga SB, Ralf A, Vermeulen M, de Kniff P, Kayser M (2012) A new future of forensic Y-chromosome analysis: rapidly mutating Y-STRs for differentiating male relatives and paternal lineages. Forensic Sci Int Genet 6:208-218

63. Ballantyne KN, Ralf A, Aboukhalid R, Achakzai NM, Anjos MJ, Ayub Q, Balažic J, Ballantyne J, Ballard DJ, Berger B, Bobillo C, Bouabdellah M, Burri H, Capal T, Caratti S, Cárdenas J, Cartault F, Carvalho EF, Carvalho M, Cheng B, Coble MD, Comas D, Corach D, D'Amato ME, Davison S, de Knijff P, de Ungria MCA, Decorte R, Dobosz T, Dupuy BM, Elmrghni S, Gliwiński M, Gomes SC, Grol L, Haas C, Hanson E, Henke J, Henke L, Herrera-Rodríguez F, Hill CR, Holmlund G, Honda K, Immel UD, Inokuchi S, Jobling
MA, Kaddura M, Kim JS, Kim SH, Kim W, King TE, Klausriegler E, Kling D, Kovačević L, Kovatsi L, Krajewski P, Kravchenko S, Larmuseau MHD, Lee EY, Lessig R, Livshits LA, Marjanović D, Minarik M, Mizuno N, Moreira H, Morling N, Mukherjee M, Munier P, Nagaraju J, Neuhuber F, Nie S, Nilasitsataporn P, Nishi T, Oh HH, Olofsson J, Onofri V, Palo JU, Pamjav H, Parson W, Petlach M, Phillips C, Ploski R, Prasad SPR, Primorac D, Purnomo GA, Purps J, Rangel-Villalobos H, Rębała K, Rerkamnuaychoke B, Gonzalez DR, Robino C, Roewer L, Rosa A, Sajantila A, Sala A, Salvador JM, Sanz P, Schmitt C, Sharma AK, Silva DA, Shin KJ, Sijen T, Sirker M, Siváková D, Škaro V, Solano-Matamoros C, Souto L, Stenzl V, Sudoyo H, Syndercombe-Court D, Tagliabracci A, Taylor D, Tillmar A, Tsybovsky IS, Tyler-Smith C, van der Gaag KJ, Vanek D, Völgyi A, Ward D, Willemse P, Yap EPH, Yong RYY, Pajnič IZ, Kayser M (2014) Toward male individualization with rapidly mutating Y-chromosomal short tandem repeats. Hum Mutat 35:1021-1032

64. Adnan A, Ralf A, Rakha A, Kousouri N, Kayser M (2016) Improving empirical evidence on differentiating closely related men with RM Y-STRs: a comprehensive pedigree study from Pakistan. Forensic Sci Int Genet 25:45-51 